\title{
PERANCANGAN TATA LETAK PABRIK DAN ANALISIS EKONOMI PADA PT XYZ EXTENSION
}

\author{
${\text { Iveline Anne } \text { Marie }^{1} \text { dan Teofilus Nathanael Chaiyadi }}^{2}$ \\ ${ }^{1}$ Program Studi Teknik Industri, Universitas Trisakti \\ ${ }^{2}$ Program Studi Teknik Industri, Universitas Tarumanagara \\ e-mail: teofilusn@yahoo.com; ivelineannemarie@yahoo.com
}

\begin{abstract}
ABSTRAK
CBA GROUP akan melakukan ekspansi dengan memproduksi bahan HDPE yang selama ini diperoleh dari supplier sebagai bahan campuran untuk memproduksi kantung plastik. Pabrik ini akan dibangun dengan kapasitas awal 182 ton/bulan. Penelitian ini bertujuan untuk merancang tata letak pabrik baru berdasarkan pendekatan Systematic Layout Planning dan melakukan analisis keuangan dalam pembangunan proyek ini. Perancangan tata letak dimulai dengan pembuatan OPC, perhitungan routing sheet, penentuan fasilitas pendukung yang diperlukan serta kebutuhan area untuk tiap fasilitas pabrik. Dilakukan analisis keterkaitan antar fasilitas pabrik secara keseluruhan dengan metode kualitatif. Berdasarkan hubungan kedekatan pada ARC Pabrik, dilakukan perancangan tata letak menggunakan metode Relationship Diagramming untuk mendapatkan rancangan Activity Relationship Diagram (ARD) pabrik sebagai dasar untuk merancang Area Allocation Diagram (AAD) Pabrik. Berikutnya, dirancang 3 alternatif tata letak yang diuji dengan metode scoring berdasarkan jarak terdekat dan menggunakan checklist Material Handling Evaluation Sheet. Setelah layout yang terpilih sudah ditentukan, selanjutnya dilakukan analisis ekonomi yang menghasilkan Harga Pokok Penjualan, Laporan Aliran kas, hasil analisis Breakeven point, Net present value, Payback Periode, Net Present Value, Internal Rate of Return, Profitability indeks (MARR) dan analisis sensitifitas.
\end{abstract}

Kata kunci: Tata Letak Pabrik, SLP, Relationship Diagramming, MHES, Analisis Ekonomi

\begin{abstract}
CBA GROUP will expand to produce HDPE material that had been obtained from the suppliers as an ingredient for the manufacture of plastic bags. The plant will be built with an initial capacity of 182 tons/month. To meet these needs, this research aims to design a new plant layout based approach Systematic Layout Planning and financial analysis in the development of this project. Designing the layout begins with the manufacture of the OPC, the routing calculation sheet, the determination of the necessary support facilities and requirements for each area of the plant facilities. An analysis of the relationship between the overall manufacturing facilities with qualitative methods. Based on the close relationship ARC Factory, to design the layout using Relationship Diagramming method to get the draft Activity Relationship Diagram (ARD) plant as a basis for designing Area Allocation Diagram (AAD) Factory. Next, designed three alternative layouts tested by the method of scoring are based on the shortest distance and use a checklist Material Handling Evaluation Sheet. After the selected layout has been determined, then performed an economic analysis that produces Cost of Sales, Cash Flow Statements, Breakeven point analysis results, Net Present Value, Payback Period, Net Present Value, Internal Rate of Return, Profitability Index (MARR) and sensitivity analysis .
\end{abstract}

Keywords: Plant Layout, SLP, Relationship Diagramming, MESH, Economic Analysis

\section{PENDAHULUAN}

PT.CBA dan PT.XYZ merupakan perusahaan yang bergerak dibidang manufaktur kantung plastik. Dalam proses pembuatan kantung plastik tidak hanya dibutuhkan bahan baku berupa biji plastik murni, tetapi diperlukan campuran bahan lain seperti HDPE atau zat aditiv lainnya.

Pada tahun 2015, PT. XYZ ingin melakukan ekspansi dengan melakukan recycling bahan HDPE yang selama ini didapatkan dari supplier. Lahan yang tersedia memiliki luas tanah $6000 \mathrm{~m}^{2}$. Berdasarkan pengalaman pembangunan PT. XYZ perusahaan menilai kriteria perancangan tata letak merupakan faktor yang penting guna menunjang aktifitas produksi. Oleh karena itu pihak perusahaan menghendaki perancangan tata letak pabrik dengan kapasitas 182 ton/bulan untuk produksi dengan tipe continous manufacturing. Tipe continous manufacturing adalah kegiatan produksi yang berlangsung 
secara terus menerus. Pihak perusahaan juga menghendaki analisis keuangan pendirian pabrik ini sebagai pertimbangan dalam pengambilan keputusan.

Batasan masalah yang digunakan dalam penelitian ini adalah kapasitas produksi yang telah ditentukan karena supply yang sudah tetap pada PT. CBA dan PT. XYZ. Lahan yang tersedia mengikuti bentuk lahan yang dimiliki.

\section{TINJAUAN PUSTAKA}

\section{Definisi Tata Letak Pabrik}

Menurut Apple tata letak pabrik adalah suatu rancangan fasilitas, membentuk konsep, dan mewujudkan sistem pembuatan barang atau jasa. Rancangan ini pada umumnya digambarkan sebagai rancangan lantai, yaitu satu susunan fasilitas fisik (perlengkapan, tanah, bangunan, dan sarana lain) untuk mengoptimalkan hubungan antara petugas pelaksana, aliran barang, aliran informasi, dan tata cara yang diperlukan untuk mencapai tujuan usaha secara ekonomis dan aman [1].

\section{Tujuan Perencanaan dan Pengaturan Tata Letak Pabrik}

Menurut Tompkins tujuan utama perencanaan dan pengaturan tata letak pabrik adalah memudahkan proses manufaktur, menaikkan output produksi, menaikkan output produksi, mengurangi waktu tunggu, mengurangi proses pemindahan bahan, penghematan penggunaan areal untuk produksi, gudang dan service[2].

\section{Perhitungan Jumlah Mesin}

Menurut Apple, lembar pengurutan produksi (routing sheet) adalah tabulasi langkah-langkah yang dicakup dalam memproduksi komponen-komponen tertentu dan perincian untuk hal-hal yang berkaitan. Tujuan pembuatan routing sheetyaitu mengetahui jumlah mesin atau peralatan produksi yang diperlukan dalam memenuhi jumlah produksi yang diinginkan dengan memperhatikan presentase scrap (sisa), kapasitas mesin, dan efisiensi mesin [1].

\section{Perhitungan Luas Lantai Produksi}

Menurut Sritomo luas lantai produksi berguna dalam memperkirakan alokasi ruang yang dibutuhkan dalam menempatkan berbagai fasilitas yang digunakan pada lantai produksi [3].

\section{Activity Relationship Chart (ARC)}

Menurut Sritomo REL-Chart akan memberikan pertimbangan mengenai derajat kedekatan (closeness) dari suatu departemen terhadap departemen lainnya dengan ukuranukuran yang lebih bersifat kualitatif seperti: mutlak atau tidak mutlak harus berdekatan, cukup penting untuk diletakkan berdekatan dan lain-lain [3].

\section{Pendekatan Algoritmik Relationship Diagramming \\ Menurut Tompkins, berdasarkan} peringkat kedekatan, penempatan antar departemen dapat menggunakan pendekatan algoritmik dimana salah satu contoh dari pendekatan algoritmik adalah metode Relationship Diagramming [2]. Metode ini merupakan dasar untuk mengkonstruksi tata letak baru yang mengutamakan departemen dengan jumlah A terbanyak. Input yang dibutuhkan adalah activity relationship chart (ARC) dan membuat worksheet dari ARC sebagai dasar konstruksi untuk activity relationship diagram (ARD).

\section{Material Handling Checklist}

Prisca andriani mengatakan "Berdasarkan Material Handle Institute (MHI) pemindahan material mencakup semua operasi dasar meliputi perpindahan barang besar dan pengemasan dalam bentuk solid antar mesin dalam area tempat kerja sebagai batasnya. Material handling checklist menggunakan aturan prinsip dasar pemindahan bahan, kriteria tata letak yang baik, dan checklist sebagai daftar mengenai hal-hal yang harus diperiksa"[4].

\section{Analisis Aspek Finansial}

Menurut Suad Husnan dan Suwarsono, Analisis finansial adalah kegiatan melakukan penilaian dan penentuan satuan rupiah terhadap aspek-aspek yang dianggap layak dari 
keputusan yang dibuat dalam tahapan analisis usaha [5].

\section{Kriteria Penilaian Investasi}

Menurut Suad Husnan dan Suwarsono, Kriteria yang diperlukan untuk menganalisis kelayakan investasi adalah Interest Rate of Return yaitu tingkat bunga yang menyamakan present value dari aliran kas keluar dan present value dari aliran kas masuk, Payback Periode yaitu metode yang mencoba mengukur seberapa cepat investasi bisa kembali, Net Present Value yaitu metode yang menghitung selisih antara nilai sekarang investasi dengan nilai sekarang penerimaan kas bersih di masa yang akan datang, Internal Rate of Return yaitu metode yang menghitung tingkat bunga yang menyamakan nilai sekarang investasi dengan nilai sekarang penerimaan-penerimaan kas bersih di masa-masa mendatang, Profitability Indeks atau $B / C$ ratio yang menunjukan keuntungan dalam nilai sekarang dibandingkan dengan investasi yang dikeluarkan dalam nilai sekarang [5].

\section{METODOLOGI PENELITIAN}

Metodologi merupakan suatu tahapan yang harus dilakukan sebelum melakukan suatu penelitian supaya penelitian dapat berjalan sesuai dengan rencana, lebih terarah dan menghasilkan hasil penelitian yang sesuai. Pemilihan metode pun akan dilakukan saat menyusun metodologi penelitian.

Data yang digunakan dalam penelitian ini diperoleh dari pabrik pada PT. XYZ. Pada pabrik baru ini akan dilakukan ekspansi dengan menambah departemen recycling bahan HDPE yang selama ini didapatkan dari supplier.
Pengolahan data dilakukan dengan metode SLP, untuk evaluasi dari hasil perancangan layout usulan dengan menggunakan metode Material handling checklist. Kemudian dilakukan analisis ekonomi yang menghasilkan Harga Pokok Penjualan, Laporan Aliran kas, hasil analisis Breakeven point, Net present value, Payback Periode, Net Present Value, Internal Rate of Return, Profitability indeks (MARR) dan analisis sensitifitas.

Diagram alir metodologi penelitian dapat dilihat pada Gambar 1.

Hasil dari perhitungan pada routing sheet menunjukkan pada operasi sorting pembulatan dilakukan ke bawah karena kapasitas yang melebih tidak mencapai 10\%. Sehingga masih bisa diatasi dengan dilakukan lembur. Waktu lembur yang diperlukan adalah 1,07 jam/minggu.

\section{Perancangan Tata Letak Fasilitas}

Pembuatan ARC menggunakan kode alasan untuk mempermudah menganalisis hubungan antar departemen baik untuk ruang produksi maupun keseluruhan pabrik. Dari kode alasan tersebut akan diberikan kode berupa A, E, I, O, U dan X sehingga memudahkan analisis hubungan kedekatan antar departemen.

Setelah dibuat worksheet ARC Produksi, dengan algroritma relationship diagramming disusunlah ARD Produksi. Dimana digunakan nilai total closeness rating $\mathrm{A}=81, \mathrm{E}=27, \mathrm{I}=9$, $\mathrm{O}=3, \mathrm{U}=1, \mathrm{X}=0$. Pembuatan ARD Produksi dimulai dengan memasukkan departemen dengan TCR tertinggi yaitu department 2 . Kemudian dianalisis departemen yang memiliki hubungan dengan nilai TCR tertinggi dengan departemen 2 yaitu departemen 1. Dengan cara

Tabel 1. Pengumpulan Data

\begin{tabular}{llll}
\hline Kapasitas Produksi/Bulan & 182 & ton/bulan (wawancara) \\
\hline Hari Kerja/Bulan & 26 & Hari & \\
\hline Jam Kerja/Hari & 7 & Jam & \\
\multirow{2}{*}{ Unit Produksi/Jam } & $182 \times 1000 \mathrm{~kg}$ & \multirow{2}{*}{$1000 \quad \mathrm{~kg} / \mathrm{jam}$} \\
\cline { 2 - 3 } & 26 hari x $7 \mathrm{jam}$ & $\%$ & \\
\hline Reliabilitas & 90 & $\%$ & \\
\hline Effisiensi Pabrik & 95 & Menit \\
\hline Set Up Time Mesin & 30 &
\end{tabular}




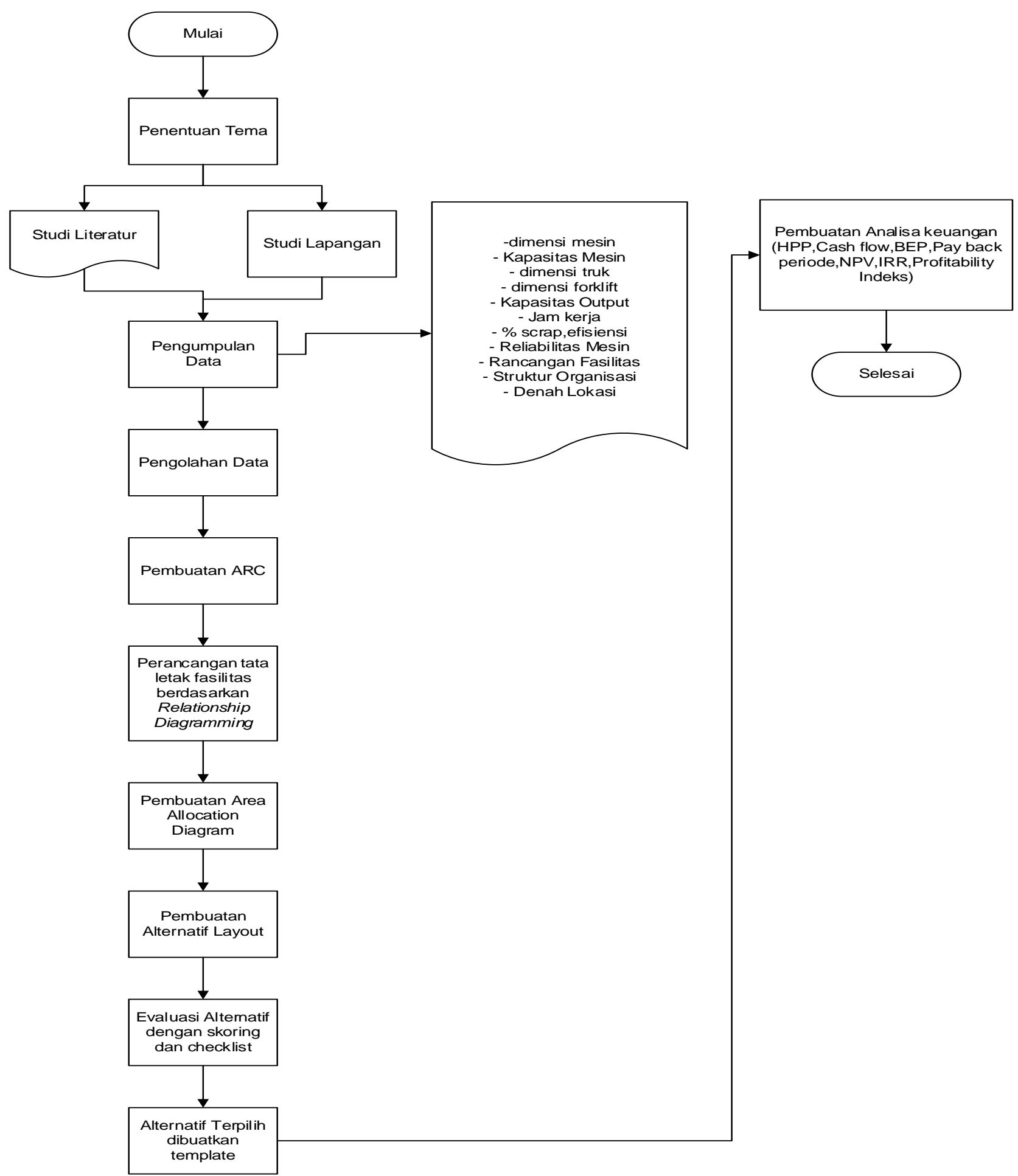

Gambar 1. Diagram Alir Metodologi Penelitian

yang sama hingga keseluruhan departemen telah terpilih.

Setelah ARD Produksi sudah selesai dirancang, selanjutnya dirancang ARC keseluruhan pabrik. Dengan Algoritma yang sama dengan Ruang Produksi dirancang ARD keseluruhan pabrik. Contoh pembuatan ARD Keseluruhan Pabrik dapat dilihat pada Gambar
2. Dimulai dengan memasukkan departemen dengan TCR tertinggi yaitu departemen 1 . Kemudian dianalisis departemen yang memiliki hubungan dengan nilai TCR tertinggi dengan departemen 1 yaitu departemen 3. Dengan cara yang sama hingga Keseluruhan Departemen telah terpilih. 


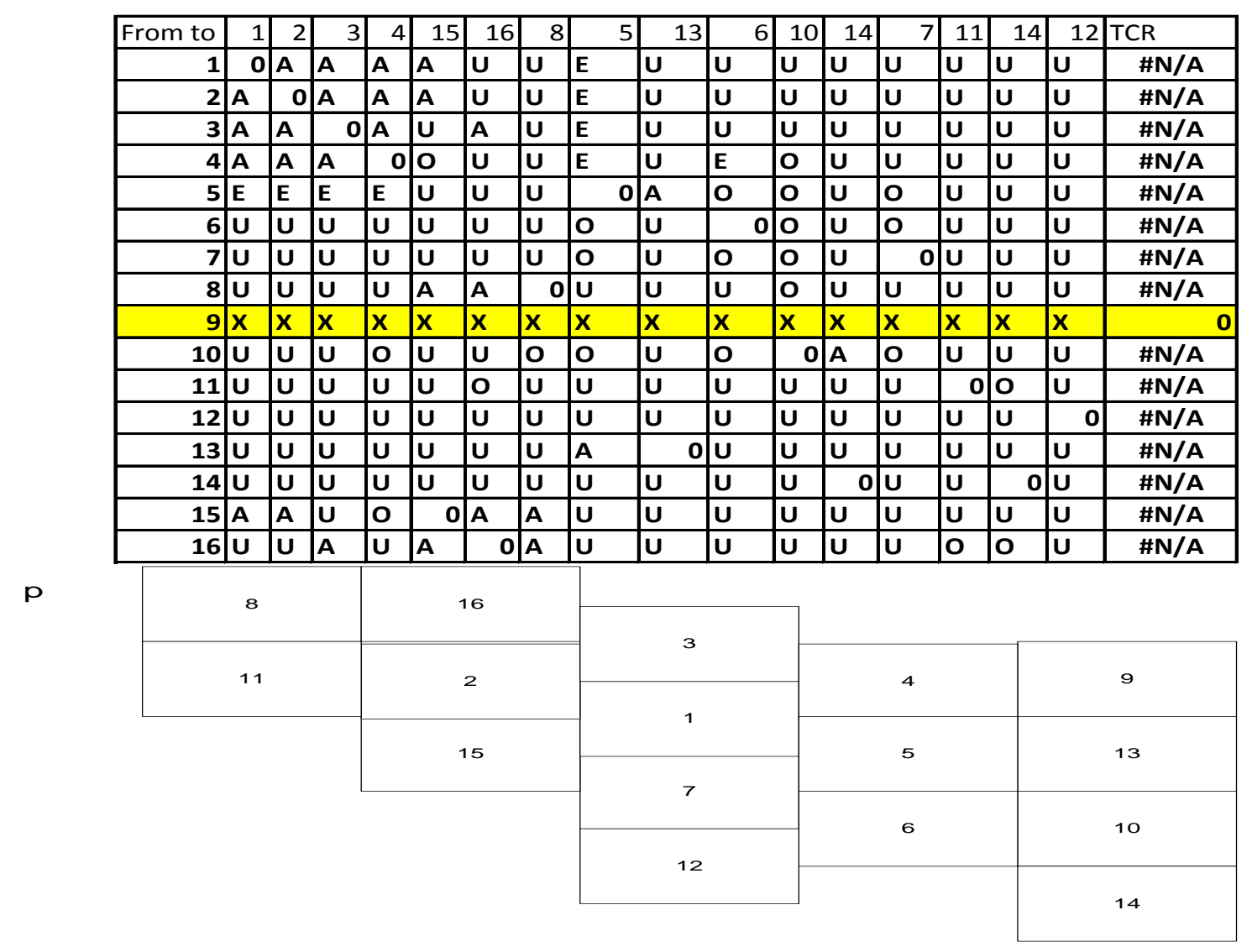

Gambar 2. Contoh Pembuatan ARD Keseluruhan Pabrik

Tabel 2. Area yang Dibutuhkan untuk Masing-Masing Fasilitas

\begin{tabular}{rlrr}
\hline No. & Departemen & Area $\left(\mathrm{m}^{2}\right)$ & Number of Unit area Templates \\
\hline 1 & Gudang Bahan Baku & 418,49 & 129,16 \\
2 & Gudang Bahan Pendukung & 3,24 & 1,00 \\
3 & Gudang Barang Jadi & 225,98 & 66,65 \\
4 & R. Produksi & 507,06 & 156,50 \\
5 & Kantor & 43,44 & 13,41 \\
6 & Parkiran Mobil & 116,90 & 36,08 \\
7 & Parkiran Motor & 57,75 & 17,82 \\
8 & Parkiran Truk & 336,00 & 103,70 \\
9 & Pembuangan Limbah & 9,00 & 2,78 \\
10 & Pos a & 5,67 & 1,75 \\
11 & Pos b & 5,67 & 1,75 \\
12 & Mushola & 109,30 & 33,73 \\
13 & Toilet R. kantor & 10,86 & 3,35 \\
14 & Loker & 12,00 & 3,70 \\
15 & Receiving & 63,00 & 19,44 \\
16 & Shipping & 79,74 & 24,61 \\
\hline & Grand Total Luas Area & 2004,10 & 609,71 \\
\hline
\end{tabular}

Dari Algoritma Relationship Diagramming dihasilkan ARD Keseluruhan yang dapat dilihat pada Gambar 3.

Langkah Selanjutnya adalah perhitungan luas lantai utama yaitu luas lantai produksi dan dilanjutkan dengan perhitungan luas lantai penunjang produksi yang dapat dilihat pada Tabel 2.
Hasil ARD yang terpilih dilanjutkan dengan membuat Area Allocation Diagram (AAD) Blockplant dimana AAD blockplant ini menggunakan luas area yang di konversi ke dalam area templates. Gambar AAD blockplant dapat dilihat pada Gambar 4.

Karena lahan yang tersedia memiliki keterbatasan maka dikembangkan 3 alternatif 


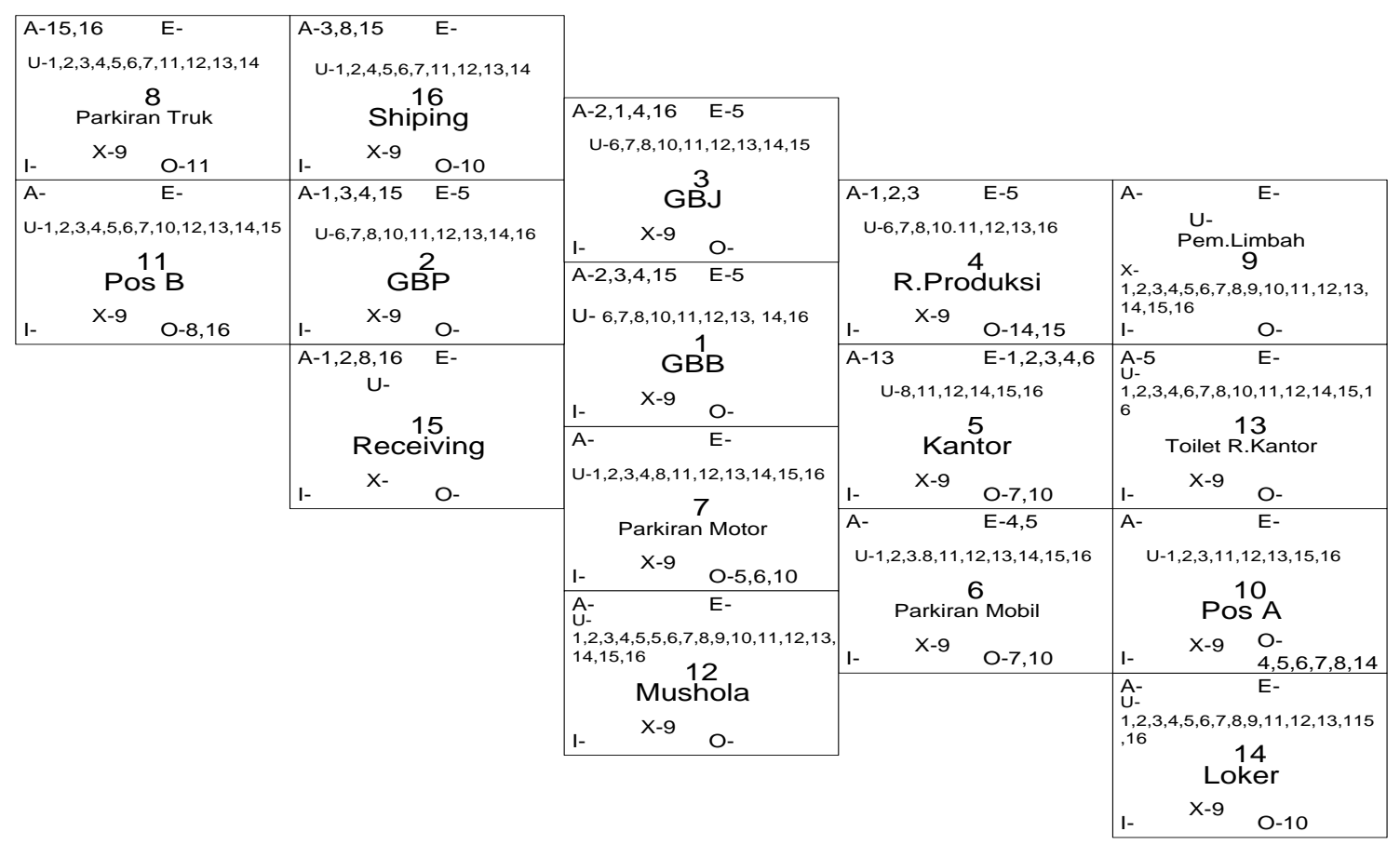

Gambar 3. ARD Keseluruhan

\begin{tabular}{|c|c|c|c|c|c|c|c|c|c|c|c|c|c|c|c|c|c|c|c|c|c|c|c|c|c|c|c|c|c|c|c|c|}
\hline \multirow{2}{*}{\multicolumn{2}{|c|}{$\frac{8}{8}$}} & & & 8 & & & & & 16 & & & & & & 3 & & 3 & & & & & 4 & & & & & & & & & \\
\hline & & & & 8 & & 16 & \begin{tabular}{l|l}
6 & 1
\end{tabular} & 1 & 16 & & & & & 3 & 3 & & 3 & & & 3 & 4 & 4 & & & & & 4 & \begin{tabular}{|c|}
4 \\
\end{tabular} & 4 & 4 & & \\
\hline 8 & 8 & & 8 & 8 & & 16 & \begin{tabular}{l|l}
6 & 1 \\
\end{tabular} & 1 & 16 & & 3 & 3 & & 3 & 3 & & & & 3 & 4 & 4 & 4 & 4 & & & & 4 & 4 & 4 & 4 & & 4 \\
\hline 8 & & & 88 & 8 & & 16 & \begin{tabular}{l|l}
6 & 1 \\
\end{tabular} & 1 & 16 & 3 & 3 & 3 & & 3 & 3 & & & 3 & 3 & 4 & 4 & 4 & & & & & & \begin{tabular}{|l|} 
\\
\end{tabular} & 4 & 4 & & 4 \\
\hline 8 & 8 & & 88 & 8 & & 16 & & \begin{tabular}{l|l}
6 & 1
\end{tabular} & $\overline{16}$ & 3 & $\overline{3}$ & $\overline{3}$ & 5 & 3 & 3 & 3 & \begin{tabular}{l|l}
3 & 3 \\
\end{tabular} & \begin{tabular}{|c|} 
\\
\end{tabular} & 3 & 4 & 4 & 4 & & & & & & \begin{tabular}{|l|}
4 \\
\end{tabular} & 4 & 4 & & 9 \\
\hline 8 & 8 & & \begin{tabular}{l|l}
8 & 8
\end{tabular} & 8 & & 15 & \begin{tabular}{l|l}
5 & 1
\end{tabular} & \begin{tabular}{l|l}
5 & 1
\end{tabular} & 2 & 1 & 1 & 1 & 1 & 1 & 1 & 1 & $\begin{array}{ll}1 & 1\end{array}$ & 1 & 4 & 4 & 4 & 4 & & & & & & 4 & 4 & 4 & & 4 \\
\hline 8 & 8 & & $\begin{array}{l}88 \\
88\end{array}$ & 8 & & 15 & \begin{tabular}{l|l}
5 & 1
\end{tabular} & \begin{tabular}{l|l}
5 & 1
\end{tabular} & 1 & 1 & 1 & 1 & 1 & 1 & 1 & 1 & 1 & 1 & 4 & 4 & 4 & 4 & & & & & & 4 & 4 & 4 & & 4 \\
\hline 8 & 8 & & $\begin{array}{l}88 \\
\end{array}$ & \begin{tabular}{l|l}
8 \\
\end{tabular} & \begin{tabular}{|l|l|}
8 & 8 \\
\end{tabular} & 15 & \begin{tabular}{l|l}
5 & 1 \\
\end{tabular} & \begin{tabular}{l|l}
5 & 1
\end{tabular} & 1 & 1 & 1 & 1 & 1 & 1 & 1 & 1 & 1 & 1 & 4 & 4 & 4 & 4 & 4 & 4 & & & 4 & 4 & 4 & 4 & & 4 \\
\hline 8 & 8 & & $\begin{array}{l}8 \\
88\end{array}$ & 8 & \begin{tabular}{|l|l|}
8 & 8 \\
\end{tabular} & 15 & \begin{tabular}{l|l}
5 & 1
\end{tabular} & \begin{tabular}{l|l}
5 & 1
\end{tabular} & $\overline{1}$ & $\overline{1}$ & 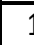 & $\overline{1}$ & 1 & 1 & 1 & 1 & 1 & 1 & 4 & 4 & 4 & 4 & & 4 & & & & 4 & 4 & 4 & & 4 \\
\hline 8 & 8 & & 88 & 8 & & 15 & $\begin{array}{ll}5 & 1 \\
\end{array}$ & $\begin{array}{l}5 \\
5\end{array}$ & 1 & 1 & 1 & 1 & 1 & 1 & 1 & 1 & 1 & 1 & 1 & 4 & 4 & 4 & & 4 & & & 4 & 4 & 4 & 4 & 4 & 4 \\
\hline 8 & 8 & 8 & $\begin{array}{l}88 \\
88\end{array}$ & \begin{tabular}{l|l}
8 & \\
\end{tabular} & & 7 & & & 1 & 1 & 1 & 1 & 1 & 1 & 1 & 1 & \begin{tabular}{l|l}
1 & 1
\end{tabular} & 1 & 1 & 4 & 4 & 4 & 4 & & & & & 4 & 4 & 5 & 5 & \begin{tabular}{l|l}
5 & 5
\end{tabular} \\
\hline 8 & 8 & 81 & \begin{tabular}{l|l|}
2 & 12
\end{tabular} & \begin{tabular}{|l|l|l|}
12 & 1 \\
\end{tabular} & \begin{tabular}{l|l|}
12 & 12
\end{tabular} & 12 & & ( & 7 & 7 & 7 & 7 & 6 & 6 & 6 & 6 & \begin{tabular}{l|l}
6 & 6
\end{tabular} & 6 & 6 & 6 & 6 & 6 & 4 & & & & & 4 & 4 & 5 & 5 & \begin{tabular}{l|l}
5 & 5
\end{tabular} \\
\hline 8 & \begin{tabular}{l|l}
8 \\
\end{tabular} & & & \begin{tabular}{|l|l|l|} 
& 12 \\
\end{tabular} & & 12 & & $\begin{array}{ll}2 & 1\end{array}$ & 7 & 7 & 7 & 7 & 6 & 6 & 6 & & \begin{tabular}{l|l}
6 & 6
\end{tabular} & 6 & 6 & 6 & 6 & 6 & & & & & & & & 5 & 5 & \begin{tabular}{l|l}
13 & 13 \\
\end{tabular} \\
\hline 8 & 8 & & \begin{tabular}{l|l}
2 & 12
\end{tabular} & 121 & & 12 & & $\begin{array}{ll}21 & 1\end{array}$ & & & & & & 6 & & & & & 6 & & & & & & & & & & & b & & $\begin{array}{lll}13 & 13\end{array}$ \\
\hline 8 & 8 & & \begin{tabular}{l|l|}
2 & 12 \\
\end{tabular} & \begin{tabular}{|l|l|}
12 & 12
\end{tabular} & & 12 & & & & & & & & & & & & & & & & & & & & & & & & & & \begin{tabular}{l|l}
10 & 10
\end{tabular} \\
\hline & 8 & & & & & & & & & & & & & & & & & & & & & & & & & & & & & & & $\begin{array}{ll}14 & 14\end{array}$ \\
\hline
\end{tabular}

\section{Gambar 4. AAD Blockplant Plant Keseluruhan}

tata letak. Alternatif tata letak dapat dilihat pada Gambar 5, Gambar 6 , dan Gambar 7.

Alternatif tata letak pertama memiliki 2 pintu masuk, gerbang sebelah kiri dikhususkan untuk kendaraan unloading dan loading. Sedangkan gerbang sebelah kanan dikhususkan untuk motor dan mobil bagian produksi maupun kantor. Luas Bangunan sebesar 66 meter x 28 meter.
Alternatif kedua hampir sama dengan alternatif pertama hanya saja gerbang untuk aktifitas loading dan unloading diletakkan disebelah kanan dikarenakan gerbang di sebelah kanan memiliki lebar yang lebih besar. Dan departemen receiving dan shipping berada di posisi lebih dekat dengan parkiran truk. Pada alternatif tata letak ini, departemen pembuangan limbah diletakkan lebih jauh sehingga tidak menggangu departemen lainnya. 


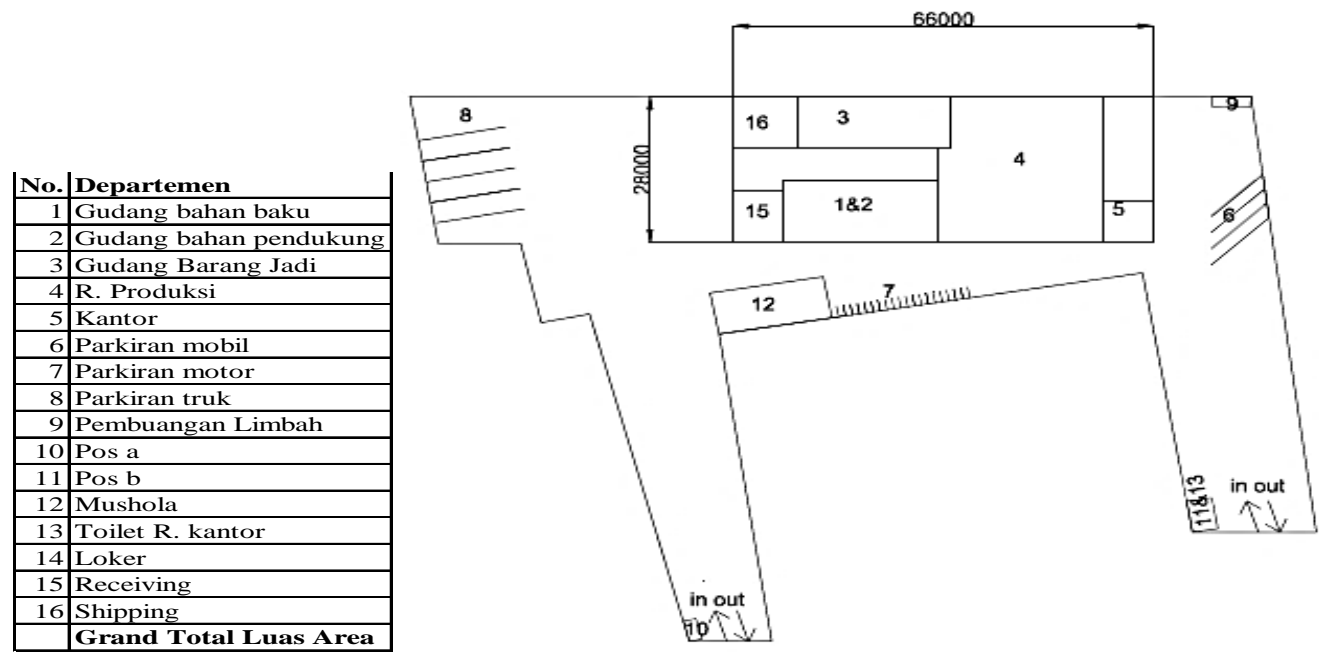

Gambar 5. Alternatif Tata Letak Pertama
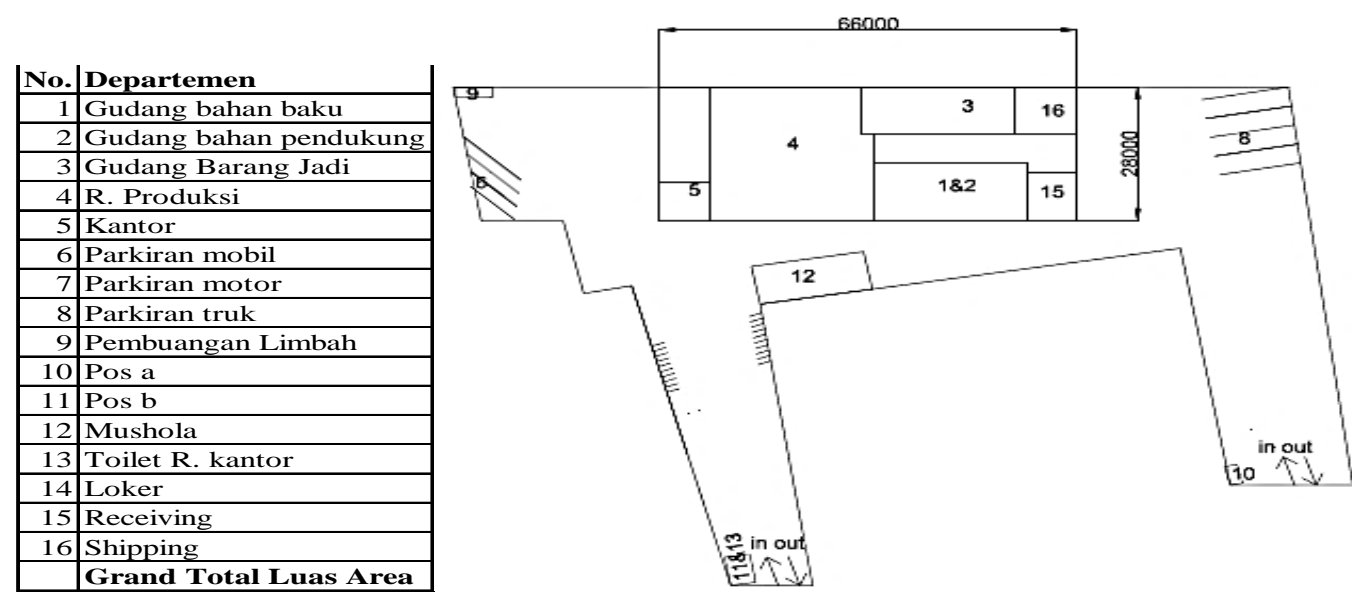

Gambar 6. Alternatif Tata Letak Kedua
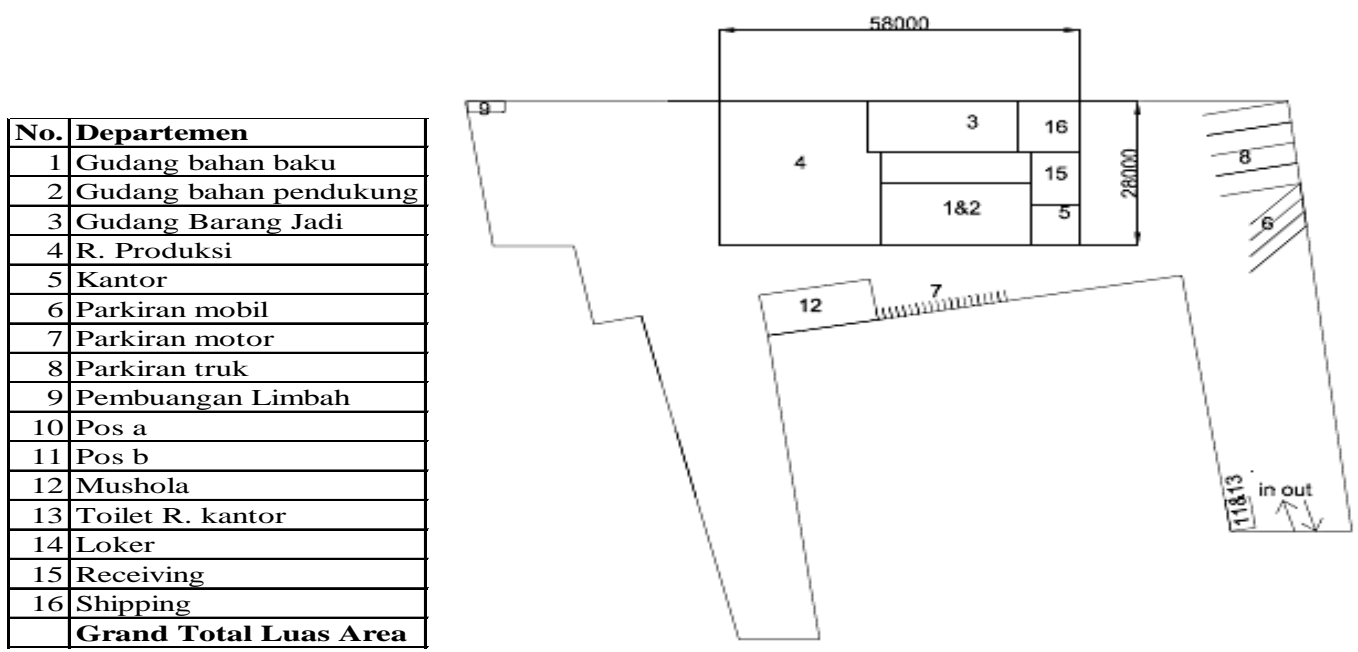

Gambar 7. Alternatif Tata Letak Ketiga

Alternatif ketiga hanya menggunakan 1 gerbang, dan posisi kantor didekatkan dengan area shipping. Serta tempat parkir untuk truk dan mobil didekatkan.

\section{Evaluasi Tata Letak}

Evaluasi tata letak dilakukan untuk mengevaluasi perancangan tata letak fasilitas pabrik dengan menyesuaikan lahan yang tersedia. Cara mengevaluasi tata letak dilakukan 
dengan 2 (dua) cara yaitu secara kuantitatif dengan skoring dan kualitatif menggunakan Material Handling Checklist. Cara pertama menggunakan Metode skoring dengan fungsi minimasi dimana digunakan kode huruf yang memiliki nilai-nilai angka, yaitu:A memiliki nilai $2^{5,}$ E memiliki nilai $2^{4}$, I memiliki nilai $2^{3}$, $\mathrm{O}$ memiliki nilai $2^{2}$, U memiliki nilai $2^{1}$, X memiliki nilai $2^{-1}$. Nilai-nilai angka tersebut akan dihubungkan dengan jarak perpindahan setiap departemen, dimana pengukuran jarak antar departemen dihitung secara rectilinear.

Hasil perhitungan skoring pengembangan alternatif tata letak dapat dilihat pada Tabel 3.

Tabel 3. Hasil Skoring Pengembangan

\begin{tabular}{cc}
\multicolumn{2}{c}{ Alternatif Tata Letak } \\
\hline Alternatif & Total Skor \\
\hline 1 & 62.220 .779 \\
2 & 58.787 .310 \\
3 & 59.957 .435 \\
\hline
\end{tabular}

Berdasarkan Tabel 3 hasil yang diperoleh dari perhitungan skoring untuk alternatif 1 yaitu 62.220.779, alternatif 2 yaitu 58.787.310, dan alternatif 3 yaitu 59.957.435. Sehingga terpilih alternatif dengan skor terendah yaitu alternatif 2. Sedangkan cara kedua, alternatif tata letak dievaluasi secara kualitatif dengan menggunakan material handling checklist. Hasil dari evaluasi menggunakan material handling checklist menunjukkan hasil yang sama yaitu terpilihnya alternatif 2 dengan total sebanyak 29. Berdasarkan kedua metode tersebut didapatkan alternatif kedua merupakan alternatif yang terbaik, sehingga diputuskan alternatif kedua yang terpilih.

\section{Analisis Ekonomi}

Analisis ekonomi dilakukan untuk mengetahui kelayakan pendirian pabrik recycling HDPE, tahapan analisis dimulai dengan melakukan perhitungan investasi awal, besar penyusutan tahunan, biaya variabel, biaya tetap, besar pendapatan, modal kerja, total dana yang dibutuhkan, perkiraan aliran kas selama 20 tahun.

Setelah dilakukan analisis kelayakan dengan suku bunga 8\% didapatkan hasil analisis dilihat dari nilai Net Present Value (NPV),
Internal Rate of Return(IRR), Minimum Attractive Rate of Return (MARR), Break Even Point, Net B/C Ratio, dan Payback Periode menunjukkan proyek pembangunan pabrik recycling HDPE layak untuk dilanjutkan. Hasil Analisis dapat dilihat pada Tabel 4.

Tabel 4. Hasil Analisis Kelayakan

\begin{tabular}{lr}
\hline \multicolumn{2}{c}{ Hasil Analisis Kelayakan } \\
\hline NPV & Rp18.658.501.011,63 \\
IRR & $15 \%$ \\
MARR & $7,88 \%$ \\
BEP & $95.913 \mathrm{Kg}$ \\
NET B/C RATIO & 1,902 \\
PBP & 10Tahun 26 hari \\
\hline
\end{tabular}

Setelah dilakukan pengujian sensitivitas, maka didapatkan bahwa faktor yang mempengaruhi adalah peningkatan biaya produksi produk sebesar maksimal $2 \%$, penurunan harga penjualan maksimal sebesar 2\%. Analisis sensitifitas dapat dilihat pada Tabel 5.

Analisis sensitivitas disimulasikan dengan syarat hasil analisis kelayakan menunjukkan $N P V$ positif, IRR $>$ Marr, Net $B / C>1$, dan payback periode dapat ditoleransi maksimal hingga 20 tahun.

Tabel 5. Analisis Sensitivitas

\begin{tabular}{clr}
\hline Simulasi & \multicolumn{2}{c}{ Hasil Analisis } \\
\hline & NPV & Rp10.771.977.170,13 \\
HPP Naik & IRR & $12 \%$ \\
Maksimal & MARR & $7,88 \%$ Deposito OCBC \\
$2 \%$ & BEP & $106.781 \mathrm{Kg}$ \\
& NET B/C RATIO & 1,479 \\
& PBP & 18,96 Tahun \\
\hline & NPV & Rp10.771.977.170,13 \\
Penjualan & IRR & $12 \%$ \\
Turun & MARR & $7,88 \%$ Deposito OCBC \\
Maksimal & BEP & $109.883 \mathrm{Kg}$ \\
$2 \%$ & NET B/C RATIO & 1,479 \\
& PBP & 18,96 Tahun \\
\hline Hpp naik & NPV & Rp10.739.374.661,59 \\
$2 \%$ & IRR & $12 \%$ \\
Penjualan & MARR & $108.192 \mathrm{Kg}$ \\
Turun & NEP B/C RATIO & 1,477 \\
$0.1 \%$ & PBP & 19,03 Tahun \\
\hline & NPV & $12 \%$ \\
Penjualan & IRR & Deposito OCBC \\
Turun 2 \% & MARR & Rp10.732.544.550,93 \\
HPP Naik & BEP & NET B/C RATIO \\
$0,01 \%$ & PBP & $1,88 \%$ Deposito OCBC \\
& $109.950 \mathrm{Kg}$ \\
\hline
\end{tabular}


Lanjutan Tabel 5. Analisis Sensitivitas

\begin{tabular}{clr}
\hline Simulasi & \multicolumn{2}{c}{ Hasil Analisis } \\
\hline Kenaikan & NPV & Rp7.960.638.829 \\
Suku Bunga & MARR & $15 \%$ \\
dapat & BEP & 8\% Deposito OCBC \\
Mencapai & NET B/C RATIO & $95.913 \mathrm{Kg}$ \\
$2 \%$ & PBP & 1,57 \\
& NPV & Rp10.890.839.574,24 \\
Kenaikan & IRR & $11 \%$ \\
Investasi & MARR & $7,9 \%$ Deposito OCBC \\
Awal & BEP & $102.578 \mathrm{Kg}$ \\
Maksimal & NET B/C RATIO & 1,388 \\
$20 \%$ & PBP & 19,53739531 Tahun \\
\hline
\end{tabular}

\section{KESIMPULAN}

Kesimpulan dari penelitian ini adalah sebagai berikut: fasilitas Lantai produksi dengan pola aliran $U$ pattern dengan luas lantai produksi $507 \mathrm{~m}^{2}$. Luas tersebut sudah berikut area untuk plant service dalam seperti Electrical Room, Maintenance tools room, Toilet Ruang Produksi, Water Treatment, dan area quality control inspection area. Luas Area yang digunakan baik untuk fasilitas penunjang dan area produksi adalah sebesar 2004,10 $\mathrm{m}^{2}$ yang meliputi: Gudang bahan baku, Gudang bahan pendukung, Gudang barang jadi, Ruang produksi, Kantor, Parkiran mobil, Parkiran motor, Parkiran truk, Pembuangan limbah, Pos A, Pos B, Mushola, Toilet kantor, Loker, Receiving, dan Shipping. Alternatif 2 merupakan alternatif terbaik atasa dasar komparasi di pembahasan. Investasi Awal yang diperlukan untuk proyek ini adalah sebesar Rp17.146.704.170 dengan perkiraan pengembalian modal selama 10 tahun dan 26 hari. Investasi ini diperkirakan memberikan Return on investment sebesar $15 \%$. Breakeven point dari investasi ini adalah sebesar 95.913 kg/bulan. Modal kerja yang dibutuhkan untuk menjalankan kegiatan produksi adalah sebesar Rp. 1.387.324.091. Aktifitas ekonomi daur ulang HDPE ini sangat sensitif, dimana hanya mampu mengalami kondisi kenaikan biaya produksi hingga sebesar $2 \%$, ataupun harga jual yang mengalami penurunan hingga sebesar $2 \%$. Kenaikan suku bunga mencapai $2 \%$, dan kenaikan investasi awal maksimal 20\%. Dengan suku bunga 8\% selama 20 tahun proyek ini menunjukkan Nilai NPV positif sebesar Rp 18.658.501.011,63.

\section{DAFTAR PUSTAKA}

[1]. Apple, James M., 1977, Plant Layout and Material Handling, $3^{\text {rd }}$ ed., New York: The Macmillan Company.

[2]. Tompkins, James A., John A., White, et al., 2010, Facilities Planning, Wiley: United States of America.

[3]. Wignjosoebroto, Sritomo, 2009, Tata Letak Pabrik dan Pemindahan Bahan Edisi Ketiga. Jakarta: Guna Widya.

[4]. Prisca Andriani, 2014, Tata Letak Pabrik PT. Eri Extension Cikarang, Jurnal tata letak pabrik, pp: 1-14.

[5]. Suad Husnan, dan Suwarsono, 1999, Studi Kelayakan Proyek. Yogyakarta. 